\title{
ATMOSZFÉRIKUS EREDETƯ ELEKTROMÁGNESES SUGÁRZÁS HATÁSA NYITOTT RENDSZERRE
}

\section{THE EFFECT OF ATMOSPHERIC ELECTROMAGNETIC RADIATION ON OPENED SYSTEM}

\begin{abstract}
Hodai Zoltán ${ }^{1}$, Rippelné Pethő Dóra ${ }^{2}$, Horváth Géza ${ }^{3}$, Hanák László ${ }^{4}$, Bocsi Róbert ${ }^{5}$
${ }^{1}$ Pannon Egyetem:' Mérnöki Kar, Vegyipari Müveleti Intézeti Tanszék, H-8200, Magyarország, Veszprém, Egyetem utca 10. Telefon: +36(88)624-132, H-8201 Veszprém, Pf. 158. E-mail: hodaiz@almos.uni-pannon.hu

${ }^{2}$ Pannon Egyetem, Mérnöki Kar, Vegyipari Müveleti Intézeti Tanszék, H-8200, Magyarország, Veszprém, Egyetem utca 10. Telefon: +36(88)624-177, H-8201 Veszprém, Pf. 158. E-mail: pethod@almos.uni-pannon.hu

${ }^{3}$ Pannon Egyetem, Mérnöki Kar, Vegyipari Müveleti Intézeti Tanszék, H-8200, Magyarország, Veszprém, Egyetem utca 10. Telefon: +36(88)624-450, H-8201 Veszprém, Pf. 158. E-mail: horvathg@almos.uni-pannon.hu

${ }^{4}$ Pannon Egyetem, Mérnöki Kar, Vegyipari Müveleti Intézeti Tanszék, H-8200, Magyarország, Veszprém, Egyetem utca 10. Telefon: +36(88)624-132, H-8201 Veszprém, Pf. 158. E-mail: hanakl@almos.uni-pannon.hu

${ }^{5}$ Pannon Egyetem, Mérnöki Kar, Vegyipari Müveleti Intézeti Tanszék, H-8200, Magyarország, Veszprém, Egyetem utca 10. Telefon: +36(88)624-268, H-8201 Veszprém, Pf. 158. E-mail: bocsirobert@almos.uni-pannon.hu
\end{abstract}

\begin{abstract}
Opened systems with liquid-phase (eg open-source bioreactors for different purposes) can produce very significant temperature extremes can be generated. The operation of the system is impaired, possibly completely inhibited (too low, too high temperature values). For the avoidance and optimum operation of thermodynamic inhibition thus formed, an analytical description of the heat flow of the system is necessary. The aim is to examine the possibilities of auxiliary energy in the system of heat exchange. The estimated values quantify the effects of atmospheric electromagnetic radiation on an open system. Based on the model developed in this way, increasing the complexity of the method, it may become appropriate to describe the heat flow of open systems to an appropriate level to explore the enrgia integration possibilities.
\end{abstract}

Keywords: atmospheric, electromagnetic radiation, heat flow, heat balance, opened system.

\section{Összefoglalás}

Folyadék fázisú nyitott rendszerekben (pl. különböző célú nyitott bioreaktorok) igen jelentős hőmérsékleti szélsőértékek alakulhatnak ki, ami a rendszer müködését rontja, esetleg teljes mértékben gátolhatja is (túl alacsony, túl magas hőmérsékletértékek). Az így kialakuló termodinamikai gátlás elkerülésének és optimális üzemének érdekében szükséges a rendszer hő forgalmának analitikus leírása. Cél a rendszeren belüli hőcsere lehetőségeinek, segédenergia igényének vizsgálata. A becsült értékek számszerüsítik az atmoszférikus elektromágneses sugárzás hatásait egy nyitott rendszerre. Az ilyen módon kialakított modell alapján, a módszer komplexitását növelve, alkalmassá válhat nyitott rendszerek hőforgalmának megfelelő szintű leírására, az enrgiaintegrációs lehetőségek feltárására. 
Kulcsszavak: atmoszférikus, elektromágneses sugárzás, höáram, hömérleg, nyitott rendszer.

\section{Bevezetés}

Általánosan megállapítható, hogy a termodinamikai rendszerekbe belépő hőáramok mínusz a kilépő hőáramok a müveleti egységben a hőmennyiség változását adják.

Vizsgált, nyitott rendszerünket tekintsük tökéletesen kevert üstnek (az üstben lévő folyadék hőmérséklete megegyezik a kilépő folyadékáram hőmérsékletével, (1)).

$$
Q_{b e}+Q_{\text {nyer. }}-Q_{k i}-Q_{\text {veszt. }}=\frac{d Q_{\text {medence }}}{d t}
$$

ahol Qbe: a belépő folyadék hőárama $[\mathrm{J} / \mathrm{s}]$, $\mathrm{Q}_{\mathrm{ki}}$ : a kilépő foly. höáram $[\mathrm{J} / \mathrm{s}], \mathrm{Q}_{\text {nyer. }}$ : a medencébe belépő hőáram $[\mathrm{J} / \mathrm{s}]$, Q $\mathrm{Qveszt.}_{\text {. }}$ a medencéből kilépő hőáram, hőveszteség [J/s], $\mathrm{Q}_{\text {medence: }}$ a medencében levő foly. hőmennyisége [J]. A környezetböl felvett és a környezetbe leadott höáram (Qnyer./Qveszt.) tartalmazza a mechanikai energiával bevitt, a tartályban zajló folyamatok által termelt, valamint a bevitt, közölt/-elvont höáramokat egyaránt.

Ezek alapján definiálható nyereségek: Qs: a Napból érkező rövidhullámú sugárzás, $\mathrm{Q}_{\mathrm{M}}$ : a mechanikai energiával (keverés, levegőztetés) bevitt höáram és $\mathrm{Q}_{\mathrm{B}}$ : biokémiai exoterm, oxidációs, reakcióban keletkező hőáramok. Továbbá a hőáram-nyereségek vagy -veszteségek a körülményektől függően a következők: $Q_{A}$ : atmoszférikus, hoszszúhullámú elektromágneses sugárzás, $\mathrm{Q}_{\mathrm{FP}}$ : a medence szabad folyadékfelszínének párolgásával kapcsolatos hőárama, $\mathrm{Q}_{\mathrm{FÁ}}$ : a szabad folyadékfelszínének hőátadással kapcsolatos hőárama, $\mathrm{Q}_{\mathrm{L}}$ : a medence levegőztetésével kapcsolatos hőáram, $\mathrm{Q}_{\mathrm{H}}$ : a medencében levő folyadékkal közölt/elvont hőáram, $\mathrm{Q}_{\mathrm{F}}$ : a medence falain történő hőtranszport.

\section{Elektromágneses sugárzással kapcsolatos kölcsönhatások}

A hőátadás különleges megnyilvánulási formája a hősugárzás. A Napból érkező rövidhullámú elektromágneses sugárzást mo- dellünk a teljesség igénye nélkül következőképp veszi figyelembe: nyitott rendszerünk folyadékfelszínén elnyelt globál sugárzást jó közelítéssel a (2) összefüggéssel becsülhetjük [1]:

$$
Q_{s}=Q_{s, 0}\left(1-0,0071 C_{c}^{2}\right) A_{s z}
$$

ahol Qs, 0 fajlagos solár sugárzás derült égbolt esetén, hőáramsürüség, $\left[\mathrm{W} / \mathrm{m}^{2}\right]$, Cc felhőborítottság (10-es skálán), Asz a medence felülete $\left[\mathrm{m}^{2}\right]$, Qs az elnyelt globál sugárzásból származó hőáram [W].

\subsection{Atmoszférikus, hosszúhullámú elektromágneses sugárzás}

A felmelegített földfelszín és folyadékfelszín, jó közelítéssel a felszíni hőmérsékletüknek megfelelően, az infravörös (hosszúhullámú) tartományban sugároznak. Hasonlóan a rövidhullámú sugárzáshoz, a felszíni hosszúhullámú kisugárzásának egy részét a légkörben lévő gázok és aeroszol részecskék részben elnyelik, illetve visszasugározzák. A gázok hosszúhullámú elektromágneses sugárzásra vonatkozó abszorpciója és emissziója szelektív. A legtöbb egy és kétatomos gáz a hősugarakra nézve ,átlátszó”. Viszont sok három- és több atomos gáz egyes hullámsávokban a hősugarakat elnyeli, így ezen sávokban emisszióra is képes. A nyitott rendszerünk légköri környezetében fontosabb ilyen gázok, gőzök vannak jelen: széndioxid, ammónia, kén-dioxid, vízgőz [2-5].

A felszíni hosszúhullámú kisugárzásra vonatkozó összefüggés [6] a medence folyadékfelszínéről a világür felé a (3) összefüggéssel vehetö figyelembe [13]:

$$
Q_{k i}=\varepsilon_{\text {foly. }} \sigma\left(T_{s z}+273\right)^{4}
$$

ahol $\varepsilon_{\text {foly. }}$ a foly. felszínének relatív emisszióképessége, $\sigma$ a Stefan-Boltzmann állandó $\left[5,67 * 10-8 \mathrm{~W} / \mathrm{m}^{2} / \mathrm{K}^{4}\right]$ és Tsz a szennyvíz hőmérséklete $\left[{ }^{0} \mathrm{C}\right]$ [7].

A légköri visszasugárzás a vízszintes síkra a felső légtérből érkező összes hosszúhul- 
lámú sugárzás. Az atmoszférából visszasugárzott és a rendszerünk foly. felszínén elnyelt hőáramsürüség $(4)[6,7]$ :

$$
Q_{\text {atm. }}=(1-\lambda) \varepsilon_{\text {égbolt }} \sigma\left(T_{\text {égbolt }}\right)^{4}
$$

ahol $\lambda$ a folyadék felületének relatív sugárzás-visszaverö képessége, $\varepsilon_{\text {égbolt }}=1$, mert az égbolt abszolút fekete testként viselkedik [1], Tégbolt a sugárzó „test” felületi hömérséklete $[\mathrm{K}]$.

Az előző közelítő összefüggés „csak” a felhőborítottságot veszi figyelembe, pedig egyéb légköri jellemzők is befolyásolják a hosszúhullámú visszasugárzás intenzitását. A felhőborítottságon túlmenően a felhők magassága, minősége, a levegő összetétele, különösen az üvegházhatást okozó gázok koncentrációja, a vízgőz parciális nyomása, füst, köd, stb. [3-5] szintén befolyásolja a hosszúhullámú visszasugárzás intenzitását.

A kapcsolódó közlemények jelentős részében ezért javasolnak egy atmoszférikus sugárzási faktor $/ \beta /$ bevezetését, amely az aktuális atmoszféra „összetételére” jellemző [1-3]. A $\beta$ értéke $0,75-0,95$ intervallumban változik [1] a leggyakoribb meteorológiai és környezeti körülmények között. A környező levegő által visszasugárzott és a folyadék felszínén elnyelt hőáramsürüséget így az (5) összefüggéssel becsülhetjük [1]:

$$
Q_{\text {vissza }}=(1-\lambda) \beta \sigma\left(T_{\text {lev. }}+273\right)^{4}
$$

ahol $\lambda$ a foly. felületének relatív sugárzásvisszaverő képessége $(0,03), \beta$ atmoszférikus sugárzási faktor $(0,75-0,95)$ [1], $\mathrm{T}_{\text {lev. }}$ a környező levegő hőmérséklete $\left[{ }^{\circ} \mathrm{C}\right]$.

\section{A teljes elektromágneses sugár- zási egyenleg}

A vizsgált rendszerben a medence számára hőnyereséget jelentő tagokat (globálsugárzás, légköri visszasugárzás) pozitívnak, a veszteséget jelentő tagokat (légköri kisugárzás) negatívnak vesszük (6).
$Q_{s t}=Q_{s}+Q_{v i s s z a}-Q_{k i}=Q_{s}-Q_{A}$

\section{Eredmények}

A fenti (1)-(6) összefüggések (komplex egyenletrendszer sarokpontjai a teljesség igénye nélkül) alapján már elvégezhetőek a modellszámítások a fajlagos, $1 \mathrm{~m}^{2}$ folyadék felületre.

A számoláshoz szükséges legfontosabb paraméterek értékei: $\sigma$ Stefan-Boltzmann állandó [5,67*10-8 W/m $\left./ \mathrm{m}^{2} / \mathrm{K}^{4}\right], \varepsilon_{\text {foly }}$ a folyadék felszínének relatív emisszióképessége $[0,97], \lambda$ a szennyvíz felületének relatív sugárzás-visszaverő képessége $[0,03], \beta$ atmoszférikus sugárzási faktor $[0,75]$ értékeknek választva végezzük számításainkat.

A jelen dolgozatban bemutatott modell 10, 16 és $20^{\circ} \mathrm{C}$-os folyadékhőmérsékletek esetére számítja ki felületek teljes elektromágneses sugárzási egyenlegeit a különböző, Magyarországot jellemző meteorológiai adatok figyelembe vételével.

A kialakított modell általi eredményt az 1. ábra mutatja.

A becsült értékek számszerüsítik az atmoszférikus elektromágneses sugárzás hatásait nyitott rendszerekre. 1. ábrán jól látható az évszakok szerint ilyen módon várhatóan kialakuló hő veszteség és többlet, amelyet kezelni szükséges. A modell komplexitását növelve (hőátadás, folyadékfelszín párolgása miatti hőáram, levegőztetés hỏárama, reakciós hők, falon keresztüli höáramok, mechanikai hőáram), alkalmassá tehető a rendszer hőforgalmának megfelelő szintü leírására, az enrgiaintegrációs lehetőségek feltárására.

\section{Köszönetnyilvánítás}

A kutatás a TÁMOP 4.2.4.A/2-11-12012-0001 Nemzeti Kiválóság Program címü kiemelt projekt keretében zajlott. A projekt az Európai Unió támogatásával, az Európai Szociális Alap társfinanszírozásával valósult meg. 


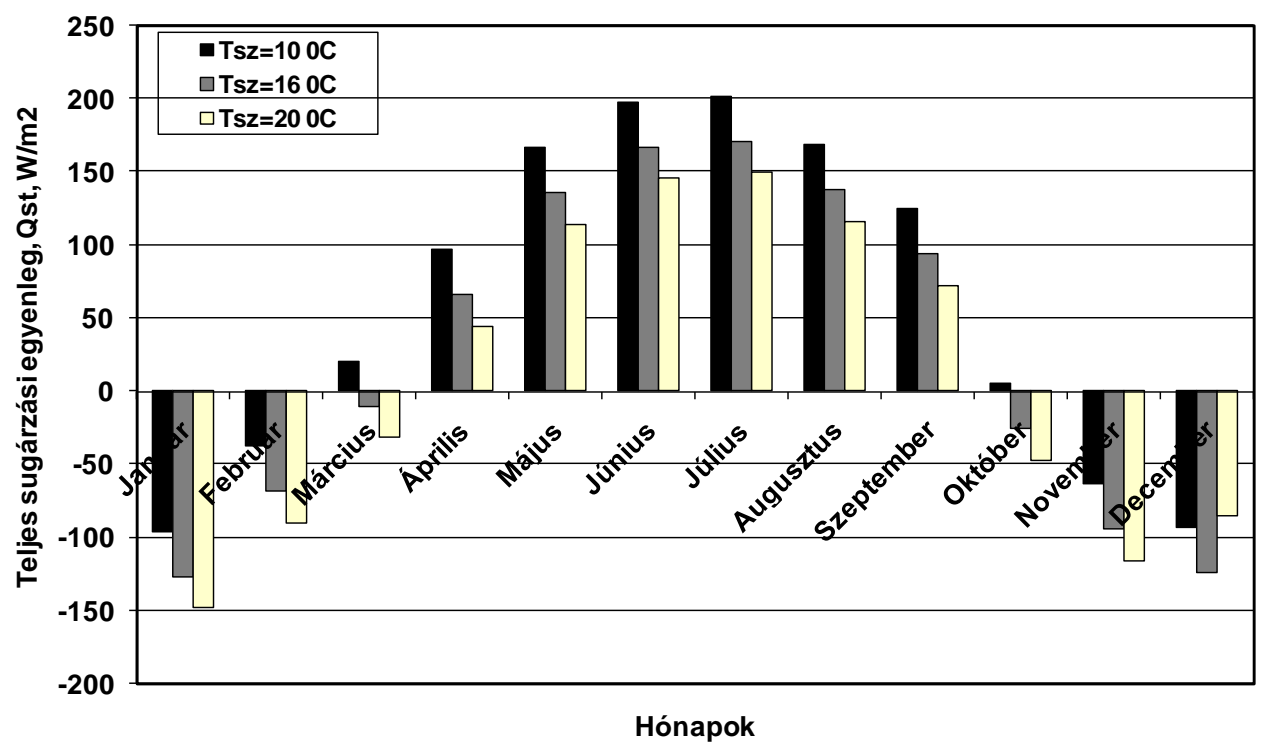

1. ábra. Teljes sugárzási egyenleg, havi átlag adatai, $T=10,16$ és $20{ }^{\circ} \mathrm{C}$ valamint $\beta=0,75$ érték esetén

\section{Szakirodalmi hivatkozások}

[1] S. N. Talati and M. K. Stenstrom, Member, Asce Aeration-Basin Heat Loss, Journal of Environmental Engineering, 116(1) 1990, 70-87.

[2] Jacobs, A.F.G., Heusinkveld, B.G., Berkowicz, S.M.: Passive dew collection in a grassland area, The Netherlands. Atmospheric Research. 87., 2008. 377-385.

[3] Kiehl, J.T. és Trenberth, K.E.: Earth's Annual Global Mean Energy Budget. Bulletin of Amererican Meteorological Society. 78., 1997. 197-208.

[4] Mészáros, R., Horváth, L., Weidinger, T., Neftel, A., Nemitz, E., Dämmgen, U., Cellier,
P., és Loubet, B.: Masurement and modelling ozone fluxes over a cut and fertilized grassland. Biogeosciences. 6., 2009. 1987-1999.

[5] Mileta, M., Beyens, D., Nikolayev, V., Milimouk, I., Clus, O., és Muselli M.: 2007. Fog and Dew Collection Projects in Croatia. Proc. International Conference on "Water Observation and Information System for Decision Support". (BALWOIS 2006), Ohrid, Republic of Macedonia, 23-26 May 2006.

[6] Argyelán J.: Transzportfolyamatok, Pannon Egyetemi Kiadó, Veszprém, 2009. 159-174.

[7] H. Faltin: Müszaki hötan, Müszaki Könyvkiadó, Budapest, 1970. 342-357. 